\title{
Ownership Structure, Corporate Governance and Corporate
}

\author{
Performance \\ Mingwei Zhou*, Yupeng Huang \\ School of Economic and Management in Nanjing University of Science and Technology, \\ China \\ *Corresponding author:Mingwei Zhou, Associate Professor, zhoumw@163.com
}

\begin{abstract}
This article selects the GEM data as to conduct a regression analysis. The results show that the GEM listed companies appear dominance, internal and actual control on the listed companies. The results show that there is a negative correlation between benefits and equity, while the members of the board of directors and senior management shareholding present a positive correlation with the return on equity. Directors' remuneration and Tobin's Q value is positively correlated. Based on the analysis of the ownership structure and corporate governance, this paper we put forward some reasonable suggestions.
\end{abstract}

Key words: ownership structure; corporate governance; corporate performance

\section{Introduction}

The GEM was listed on the Shenzhen stock exchange on October 23, 2009.China has experienced a 10\% annual GDP growth, and the national income level remarkably increases, thus expand residents investment demand. The market-oriented reforms of interest rate make the linkage between monetary market and the capital market stronger. The listed companies on GEM were founded in a short time, so the asset scale is small, and the main business is one-fold, it also being with the characteristics of high price earnings ratio, high price, high profit, high growth and a concentrated equity distribution. The family business ownership, one share being in dominated proportion, lead to a strong control and actual influence on the board of directors of the listed company.

The core of modern corporate system is to establish a sound corporate governance mechanism, and the equity structure is an important part of the corporate governance structure. In recent years, the research of the domestic scholars focused on the main board market, which they concluded that there is a certain relationship between ownership structure and corporate performance. However, the research of the GEM market is still severly scarce. The main board listed companies are mature and stable enterprises, while the GEM is still in a relatively short time, neither the regulatory laws nor the regulation system are perfect. So whether the main market research results can be adapted to the GEM market has been unknown yet. In 
order to fill the gap in this regard, we choose the GEM market to analyze the relationship between ownership structure, corporate governance and corporate performance.

Domestic and foreign scholars carried out researches mainly from the respect of the corporate governance and the equity structure. Demsetz.H (1983) using the accounting profit indicators and the number of the top ten shareholders to carry out an empirical analysis, the results show that the relationship between the two are not significant. Thomsen and Perderson (2001) find that equity concentration and corporate performance are positively correlated through a study on 453 large companies in Europe. Mcconnell and Servaes H. (1990) show that the relationship between firm performance and the number of professional managers is presented as a "U". Zhu (2012) believes that the balance of ownership and corporate performance is positively correlated with the stock market and the corporate performance in China's GEM market. Ying Long, Shiyin Zhang (2009) found that there is no correlation between the proportion of tradable shares and the company's operating performance with the 38 listed companies of A stock market in Anhui Province. Zhou (2010) find that the proportion of tradable shares and corporate performance in the pharmaceutical industry is a relatively weak positive correlation. Sun Jingshui, Yu Lifeng (2007) and YushengWang (2008) believe that the proportion of senior executives and corporate performance possess a significantly positive correlation.

However, the sample selection period of all the researches is before 2012, and relative index selection is single, so this article selects the three-year data of the GEM listing companies from 2013 to 2015 to analyze the relationship between corporate ownership structure and corporate performance, and select more indicators in order to reduce the moral hazard and adverse selection. Besides the studies on the effect of the shareholders' incentives to the management of the company on the performance of listed companies are relatively scarce.

\section{Research design}

\subsection{Samples and data}

The data of this paper come from Wind database.This paper we select a total of 1062 samples from 354 listed companies between 2013 and 2015. And we use the method of the panel regression to analyze. The explanatory variables, the dependent variables, and the control variables are shown in Table 1. 
Table 1- Variable description table

\begin{tabular}{|c|c|c|}
\hline Explanatory variable & CR1 & The proportion of the first largest shareholder \\
\hline & Hn & Ownership concentration \\
\hline & B3 & Proportion of board of directors \\
\hline & E4 & Senior management shareholding ratio \\
\hline & LN(m1) & The sum of the remuneration of the board of directors \\
\hline & EPS & Earnings per share \\
\hline & ROE & Return on net assets \\
\hline Control variable & TQ & Tobin Q \\
\hline & DTL & Asset liability ratio \\
\hline
\end{tabular}

\subsection{Descriptive statistics}

Table 2-Descriptive statistics of variables

\begin{tabular}{|c|c|c|c|c|c|c|c|c|c|}
\hline year & & TQ & ROE & EPS & CR1 & Hn & B3 & E4 & Ln(M1) \\
\hline N & N & 354 & 354 & 354 & 354 & 354 & 354 & 354 & 354 \\
\hline 2013 & MIN & 0.000 & 0.097 & -0.739 & 0.058 & 0.220 & 0.003 & 0.000 & 12.315 \\
\hline 2013 & MAX & 10.575 & 10.590 & 1.512 & 0.688 & 0.763 & 0.229 & 1.403 & 16.284 \\
\hline 2013 & MEAN & 2.934 & 0.529 & -0.154 & 0.331 & 0.514 & 0.066 & 0.706 & 13.921 \\
\hline 2013 & STD & 1.876 & 3.070 & 0.350 & 0.128 & 0.102 & 0.043 & 0.220 & 0.554 \\
\hline 2014 & MIN & 0.000 & 0.097 & -1.359 & 0.049 & 0.149 & 0.003 & 0.000 & 11.983 \\
\hline 2014 & MAX & 17.816 & 1.060 & 1.524 & 0.635 & 0.734 & 0.233 & 1.475 & 16.378 \\
\hline 2014 & MEAN & 3.015 & 0.530 & -0.157 & 0.315 & 0.484 & 0.064 & 0.713 & 13.998 \\
\hline 2014 & STD & 1.998 & 3.070 & 0.354 & 0.125 & 0.107 & 0.043 & 0.220 & 0.567 \\
\hline 2015 & MIN & 0.000 & 0.020 & -1.998 & 0.043 & 0.185 & 0.005 & 0.000 & 11.612 \\
\hline 2015 & MAX & 24.940 & 1.061 & 1.780 & 0.626 & 0.812 & 0.348 & 1.536 & 16.296 \\
\hline 2015 & MEAN & 5.056 & 0.531 & -0.156 & 0.297 & 0.500 & 0.065 & 0.687 & 14.094 \\
\hline 2015 & STD & 3.472 & 3.070 & 0.358 & 0.118 & 0.104 & 0.045 & 0.247 & 0.596 \\
\hline
\end{tabular}

From the results of descriptive statistics, the maximum value of Tobin's $Q$ value has increased year by year, same with the mean value. The differences among the listed companies are great, the minimum Tobin's Q value being 0 and the maximum being 24.94, which proved that the GEM listed companies' performance is quite good with the fundamentals support. Return on net assets reaches 500, and the maximum value being even more than 1000 , which further illustrates the GEM listed companies are with high yield, high growth, and the characteristics of light assets. From the view of first largest shareholder equity ratio, the average and maximum value of three years are more than $50 \%$. 


\section{Empirical analyses}

\subsection{Model building}

According to the relationship between the ownership structure, corporate governance and corporate performance, the following three models are established.

$$
\begin{aligned}
& R O E_{i}=\beta_{0}+\beta_{1} X_{i}+\beta_{2} A L+\beta_{3} D T L+\xi \\
& E P S_{i}=\beta_{0}+\beta_{1} X_{i}+\beta_{2} A L+\beta_{3} D T L+\xi \\
& T Q_{i}=\beta_{0}+\beta_{1} X_{i}+\beta_{2} A L+\beta_{3} D T L+\xi
\end{aligned}
$$

\begin{tabular}{|c|c|c|c|c|c|c|}
\hline EPSi & 1 & 2 & 3 & 4 & 5 & 6 \\
\hline Intercept & $\begin{array}{c}-0.063 \\
(-1.790)\end{array}$ & $\begin{array}{c}0.249 \\
(4.462)\end{array}$ & $\begin{array}{c}-0.193 \\
(-7.082)\end{array}$ & $\begin{array}{c}-0.129 \\
(-3.248)\end{array}$ & $\begin{array}{c}-0.911 \\
(-3.442)\end{array}$ & $\begin{array}{c}-0.224 \\
(-8.515)\end{array}$ \\
\hline CR1 & $\begin{array}{r}-0.315 \\
(-3.644)\end{array}$ & & & & & \\
\hline Hn & & $\begin{array}{c}-0.806 \\
(-8.016)\end{array}$ & & & & \\
\hline B3 & & & $\begin{array}{c}0.423 \\
(1.721)\end{array}$ & & & \\
\hline E4 & & & & $\begin{array}{c}-0.049 \\
(-1.045)\end{array}$ & & \\
\hline $\mathrm{LN}(\mathrm{m} 1)$ & & & & & $\begin{array}{c}0.053 \\
(2.826)\end{array}$ & \\
\hline AL & $\begin{array}{c}0.019 \\
(0.294)\end{array}$ & $\begin{array}{c}-0.010 \\
(-0.153)\end{array}$ & $\begin{array}{c}0.030 \\
(0.456)\end{array}$ & $\begin{array}{c}0.028 \\
(0.428)\end{array}$ & $\begin{array}{c}0.028 \\
(0.425)\end{array}$ & $\begin{array}{c}0.022 \\
(0.332)\end{array}$ \\
\hline DTL & $\begin{array}{c}0.043 \\
(0.772)\end{array}$ & $\begin{array}{c}0.412 \\
(0.746)\end{array}$ & $\begin{array}{c}0.527 \\
(0.906)\end{array}$ & $\begin{array}{c}0.479 \\
(0.847)\end{array}$ & $\begin{array}{c}0.504 \\
(0.891)\end{array}$ & $\begin{array}{c}0.528 \\
(0.939)\end{array}$ \\
\hline R-Squared & 0.013 & 0.058 & 0.004 & 0.002 & 0.008 & 0.016 \\
\hline
\end{tabular}

\subsection{Results of regression analysis}

Table 3- Regression analysis between earnings per share and variables

From the results of the earnings per share and the explanatory variables in the regression analysis, the largest shareholder equity ratio and earnings per share have a negative correlation, and it being tested through the significant test. The wealth of shareholders can't be increased, especially the interests encroach on the minority shareholders. The ownership concentration degree and corporate performance are negatively correlated, which is not conducive to increase the competitiveness of the company. The shareholding proportion of the board of directors and the income of the top executives are positively related to the corporate performance, which also passed the significant test. The separation of ownership and management rights can increase shareholder compensation, but also can satisfy the interests of 
other stakeholders.

Table 4-Return on net assets and the regression analysis between the variables

\begin{tabular}{|c|c|c|c|c|c|c|}
\hline ROEi & 1 & 2 & 3 & 4 & 5 & 6 \\
\hline Intercept & $\begin{array}{c}4.683 \\
(15.441)\end{array}$ & $\begin{array}{c}1.499 \\
(3.159)\end{array}$ & $\begin{array}{c}5.931 \\
(25.211)\end{array}$ & $\begin{array}{c}5.554 \\
(16.111)\end{array}$ & $\begin{array}{c}7.719 \\
(3.371)\end{array}$ & $\begin{array}{c}6.077 \\
(26.559)\end{array}$ \\
\hline CR1 & $\begin{array}{c}3.454 \\
(4.6441)\end{array}$ & & & & & \\
\hline Hn & & $\begin{array}{c}8.384 \\
(9.801)\end{array}$ & & & & \\
\hline B3 & & & $\begin{array}{c}-1.926 \\
(-0.907)\end{array}$ & & & \\
\hline E4 & & & & $\begin{array}{c}0.351 \\
(0.861)\end{array}$ & & \\
\hline $\mathrm{LN}(\mathrm{m} 1)$ & & & & & $\begin{array}{l}-13.646 \\
(-0.836)\end{array}$ & \\
\hline AL & $\begin{array}{c}-1.677 \\
(-2.923)\end{array}$ & $\begin{array}{c}-1.343 \\
(-2.412)\end{array}$ & $\begin{array}{c}-1.761 \\
(-3.038)\end{array}$ & $\begin{array}{c}-1.750 \\
(-3.019)\end{array}$ & $\begin{array}{l}-1.7737 \\
(-3.049)\end{array}$ & $\begin{array}{c}-1.722 \\
(-2.974)\end{array}$ \\
\hline DTL & $\begin{array}{c}-0.388 \\
(-0.803)\end{array}$ & $\begin{array}{c}-0.369 \\
(-0.789)\end{array}$ & $\begin{array}{c}-0.461 \\
(-0.945)\end{array}$ & $\begin{array}{c}-0.442 \\
(-0.091)\end{array}$ & $\begin{array}{c}-0.454 \\
(-1.008)\end{array}$ & $\begin{array}{c}-0.468 \\
(-1.103)\end{array}$ \\
\hline R-Squared & 0.029 & 0.092 & 0.010 & 0.010 & 0.010 & 0.013 \\
\hline
\end{tabular}

And from the variables of the regression analysis of the rate of return on net assets, the largest shareholder and equity concentration are in a significant positive correlation with the rate of return on net assets. Through the test of significance, the GEM listed company managers and shareholders have more serious adverse selection and moral hazard, managers' purposes being deviated from the shareholders' goal, managers tending to increase their own compensation, and gaining a better work environment at the expense of the shareholder's interests.

The results show that the shareholding ratio of the first largest shareholder failed to pass the significant test, while ownership concentration degree and Tobin's Q values show a positive correlation and passed the significant test, which illustrats that there is a game among the major shareholders of listed companies and the game can effectively increases the company value. The board of directors and professional managers tend to expand the size of the company and unceasingly boost market value of the company, which in some degree can also increase shareholders' rights and interests, but from the point of asset liability ratio and leverage, all being showed a significant negative correlation with Tobin’s Q value. 
Table 5- Regression analysis between Tobin’s Q and variables

\begin{tabular}{|c|c|c|c|c|c|c|}
\hline TQi & 1 & 2 & 3 & 4 & 5 & 6 \\
\hline Intercept & $\begin{array}{c}4.567 \\
(17.007)\end{array}$ & $\begin{array}{c}3.664 \\
(8.478)\end{array}$ & $\begin{array}{c}4.766 \\
(23.157)\end{array}$ & $\begin{array}{c}4.613 \\
(15.296)\end{array}$ & $\begin{array}{c}0.563 \\
(0.282)\end{array}$ & $\begin{array}{c}4.362 \\
(21.834)\end{array}$ \\
\hline CR1 & $\begin{array}{c}0.371 \\
(0.565)\end{array}$ & & & & & \\
\hline Hn & & $\begin{array}{c}1.993 \\
(2.559)\end{array}$ & & & & \\
\hline B3 & & & $\begin{array}{c}-1.172 \\
(-0.631)\end{array}$ & & & \\
\hline E4 & & & & $\begin{array}{c}0.105 \\
(0.294)\end{array}$ & & \\
\hline $\mathrm{LN}(\mathrm{m} 1)$ & & & & & $\begin{array}{c}0.295 \\
(2.077)\end{array}$ & \\
\hline AL & $\begin{array}{c}-3.602 \\
(-7.094)\end{array}$ & $\begin{array}{c}-3.512 \\
(-6.925)\end{array}$ & $\begin{array}{c}-3.614 \\
(-7.125)\end{array}$ & $\begin{array}{c}-3.608 \\
(-7.113)\end{array}$ & $\begin{array}{c}-3.676 \\
(-7.250)\end{array}$ & $\begin{array}{c}-3.650 \\
(-7.220)\end{array}$ \\
\hline DTL & $\begin{array}{c}-0.363 \\
(-0.849)\end{array}$ & $\begin{array}{c}-0.352 \\
(-0.822)\end{array}$ & $\begin{array}{c}-0.376 \\
(-0.880)\end{array}$ & $\begin{array}{c}-0.367 \\
(-0.861)\end{array}$ & $\begin{array}{c}-0.568 \\
(-0.843)\end{array}$ & $\begin{array}{c}-0.348 \\
(-0.818)\end{array}$ \\
\hline R-Squared & 0.046 & 0.052 & 0.046 & 0.046 & 0.051 & 0.053 \\
\hline
\end{tabular}

\section{Conclusions and recommendations}

In this paper, we take the data of listed companies in our country as the research sample from 2013 - 2015 to study the impact of corporate governance on corporate performance of listed companies in GEM. The empirical research conclusions are: the first big shareholder's stake and the degree of the equity concentration show a significant negative correlation with earnings per share; executive income and the return on net assets present a significant negative correlation relationship; the first big shareholder ownership and ownership concentration are in a significant positive correlation with the rate of the return on equity, and directors and executive compensation and Tobin's $\mathrm{Q}$ value are in a significant positive correlation; the impact of other explanatory variables on corporate performance is not significant.

At last, we put forward the following suggestions. Firstly, to actively cultivate and introduce strategic institutional investors who are rich in social resources, and with a strong ability to withstand market risks. Secondly, optimizing equity allocation to promote equity concentration remains in a reasonable range, the state should publish relevant policy to start the GEM equity market reform, and actively guide other legal person shares, the ownership structure of state-owned shares in the optimization of the GEM listed companies. Thirdly, to 
encourage company management and employee stock ownership structure to optimize the ownership structure of listed companies. Improving corporate performance, employee stock ownership will play a positive role in the supervision of the management of listed companies.

\section{References}

1.H. Demsetz, The Structure of Ownership and the Theory of the Firm[J]. Journal of Law \& Economics, 1983, 26(2):375-90.

2.T.Pedersen, S.Thomsen, The Causal Relationship between Insider Ownership, Owner Identity and Market Valuation among the Largest European Companies[J]. Working Papers, 2001.

3.Mcconnell, H. Servaes, Additional evidence on equity ownership and corporate value [J]. Journal of Financial Economics, 1990, 27(2):595-612.

4.Y.H. Tu, An empirical study on the relationship between ownership structure and corporate performance of private listed companies[D]. Jiangxi University of Finance and Economics, 2010.

5.H.J. Zhou, China's pharmaceutical industry ownership structure on corporate performance of [D]. Northwestern University, 2010.

6.L.W. Zhu, Equity balance and company performance -- from the gem empirical evidence [J]. Economic Forum, 2012 (9): 101-104.

7.Y. An, T.Y. Zhong, An empirical study on the relationship between ownership concentration, ownership restriction and corporate performance: An Empirical Analysis Based on Chinese manufacturing listed companies [J]. Journal of Northeast Normal University: Philosophy and Social Science Edition, 2011 (6): 46-52.

8.M.H. Gao, J. Yang, Analysis on the influencing factors of corporate governance performance of Listed Companies in China [J]. international financial research, 2002 (11): 54-58.

9.Y. Long, S.Y Zhang, Empirical Study on the relationship between capital structure and corporate performance: Based on the analysis of Listed Companies in Anhui province [J]. statistical education, 2009 (12): 30-33.

10.J.S. Sun, L.F. Yu, Empirical analysis of ownership structure and operating performance of private listed companies -- Taking Zhejiang Province as an example [J]. industrial technology economy, 2007, 26 (6): 139-142.

11.Y. Wang, Empirical Study on ownership structure and corporate performance [J]. financial accounting communication: Academic Edition, 2008 (11): 18-21. 